\title{
Analiza radnih obilježja šumskih kamionskih skupova za prijevoz drva
}

\author{
Marijan Šušnjar, Marin Bačić, Tomislav Horvat, Zdravko Pandur
}

\begin{abstract}
Nacrtak - Abstract
U radu je provedeno istraživanje petnaest različitih šumskih kamionskih skupova za prijevoz drva u vlasništou poduzeća Hrvatske šume d.o.o. Zagreb, Uprava šuma podružnica Bjelovar. Osnovni podaci koji su korišteni za analizu šumskih kamionskih skupova za prijevoz drva su: prijeđeni kilometri (pun, prazan), ukupna potrošnja goriva, broj dana rada (u radu, u kvaru, ispravni izvan rada), prevezeno drvo, broj tura, starost i tip vozila. Analizom podataka iskazana je potrošnja goriva prema više kriterija, stupanj iskorištenosti i tehničke ispravnosti kamionskih skupova te odnos vožnje s obzirom na relaciju pun - prazan. Na osnovi rezultata istraživanja donosi se preporuka za organizacijska rješenja kamionskoga prijevoza drva $i$ smjernice $z a$ unapređenje i modernizaciju tehničkih rješenja na šumskim kamionskim skupovima.
\end{abstract}

Ključne riječi: šumski kamionski skup, potrošnja goriva, tehnička ispravnost, stupanj iskorištenosti

\section{Uvod - Introduction}

Daljinski ili sekundarni prijevoz drva odvija se po javnim i šumskim cestama ili željezničkim prugama, odnosno vodenim putovima od pomoćnoga stovarišta do glavnoga stovarišta - kupca (Greulich 2002). U hrvatskom šumarstvu drva se prevoze uglavnom šumskim kamionskim skupovima (Zorić 2015). Sever je (1992) imenovao različite izvedbe šumskih kamionskih skupova, ali se danas šumskim kamionskim skupom ponajprije naziva izvedba kamiona s prikolicom opremljenom hidrauličnom dizalicom (Krpan i dr. 2002, Tomašić i dr. 2005, Šušnjar i dr. 2011a). Zorić i dr. (2014) daju podatak da udio prijevoza drva šumskim kamionskim skupovima premašuje $85 \%$ u ukupnom daljinskom prijevozu drva, a danas se u Hrvatskoj gotovo svi drvni sortimenti prevoze kamionskim skupovima. Od toga većinu daljinskoga prijevoza obavljaju privatni poduzetnici i kupci drvnih sortimenta, dok trgovačko društvo Hrvatske šume d.o.o. Zagreb sudjeluje s $15 \%$ u ukupnom daljinskom prijevozu drva s vlastitim šumskim kamionskim skupovima (Tomašić i dr. 2012). Pri tome se nadalje udio trgovačkoga društva Hrvatske šume d.o.o. Zagreb u ukupnom daljinskom prijevozu drva stalno smanjuje.
Iznimno su visoki troškovi daljinskoga prijevoza drva šumskim kamionskim skupovima zbog svojstava rada kao što su: ciklički rad, velik udio vožnje neopterećenoga vozila, visoka nabavna cijena vozila, prevezene male količine jeftine robe, visoke cijene goriva i velika potrošnja goriva. Šušnjar i dr. (2011b) navode da je daljinski prijevoz drva šumskim kamionskim skupovima najskuplji oblik daljinskoga prijevoza drva, dok Svenson i Fjeld (2016) predočuju troškove daljinskoga prijevoza drva šumskim kamionima u iznosu oko $25 \%$ ukupnih troškova unutar cjelokupnoga sustava pridobivanja drva.

Da bi se povećala učinkovitost kamionskoga prijevoza drva, potrebno je provoditi svrhovite tehničke, tehnološke i organizacijske mjere. Postoji i niz ograničavajućih čimbenika koji se nalaze izvan šumskoga gospodarskoga sustava kao što su, primjerice, zakonski propisi o dimenzijama i nosivosti kamionskih skupova, ograničenje brzine vožnje, stanje i opterećenost prometnica i sl. (Carette i Ginet 2014). Guimaraes i dr. (2016) istaknuli su udaljenost vožnje, vrstu prometa i rute, prometno područje, veličinu vozila i odnos između opterećenih i neopterećenih udaljenosti putovanja kao čimbenike koji mogu značajno utjecati na iznos troškova daljinskoga prijevoza drva. 
Daljinski je prijevoz drva šumskim kamionima najveći potrošač goriva $\mathrm{u}$ cjelokupnom lancu pridobivanja drva (Ghaffariyan i dr. 2018). U Švedskoj je utrošak goriva u daljinskom prijevozu drva kamionima iznosio oko $50 \%$ ukupne potrošnje goriva sustava pridobivanja drva, dok se na sječi, izradi i privlačenju drva kretao $33-40 \%$ (Lindholm 2006).

Favreau (2006) piše da u ukupnim troškovima daljinskoga prijevoza drva kamionima trošak goriva sudjeluje s $30 \%$, dok Griffin i Brown (2010) iznose da je trošak goriva veći od $40 \%$ ukupnih troškova prijevoza drva kamionima.

Radi smanjenja troškova potrošnje goriva važno je razumjeti utjecaj različitih čimbenika na kamionski prijevoz drva. Svenson (2011) prema Klvaču (2013) nabraja niz tehničkih čimbenika koji utječu na potrošnju goriva šumskih kamionskih skupova. Čimbenike svrstava u ove skupine: svojstva vozila, svojstva prikolice, geometrija ceste, gornji ustroj šumske ceste, brzina kretanja, promjena stupnja prijenosa, način vožnje, vrijeme i uvjeti gornjega ustroja šumske ceste. Devlin (2010) govori da navedeni čimbenici značajno utječu na potrošnju goriva prilikom daljinskoga prijevoza drva kamionima, koja može biti dvostruko veća u usporedbi s prijevozom drugih vrsta roba. Prema Griffinu i Brownu (2010) na potrošnju goriva utječu tehnička svojstva kamiona (konfiguracija prikolice, motor, mjenjač, gume itd.), stanje na cesti (nagib ceste, udaljenost prijevoza, površina ceste, brzina kretanja itd.), masa tovara, način vožnje i organizacija rada (vrijeme čekanja, odnos prijeđene udaljenosti natovarenoga i praznoga kamiona). Guimaraes i dr. (2016) pri matematičkom modeliranju potrošnje goriva $u$ cestovnom kamionskom prijevozu drva kao najutjecajnije čimbenike ističu udaljenost vožnje, prosječnu brzinu kretanja i trajanje vožnje.

Konstrukcijska rješenja šumske nadogradnje šumskih kamionskih skupova onemogućuju da se vozila koriste, ili se vrlo rijetko koriste za prijevoz ostale robe (Šušnjar i dr. 2016). Stoga je organizacija rada šumskih kamionskih skupova vrlo zahtjevna radi osiguranja dovoljno radnih dana prijevoza drva ispravnih šumskih kamionskih skupova.

Šumski se kamionski skupovi tijekom dana nalaze na radu ili izvan radnoga procesa. Razlozi su zbog kojih su šumski kamionski skupovi izvan radnoga procesa neispunjavanje uvjeta opće ispravnosti (valjane dozvole vozila, certifikati te raspoloživ vozač s valjanom vozačkom dozvolom odgovarajuće kategorije ili tehničke ispravnosti (otklanjanje kvarova) te nedovoljna organizacija rada kada su tehnički ispravna vozila bez dnevnih radnih naloga. Tehnička je ispravnost vozila nužan preduvjet za djelovanje vozila (Protega 2010). Tehnički ispravni šumski kamionski skupovi također mogu biti izvan radnoga procesa upravo zbog organizacijskoga nedostatka radova, obavljanja redovitoga održavanja i tehničkoga pregleda vozila te nedostupnosti vozača.

Stoga je potrebno provoditi vremensku analizu stanja vozila koja može dati smjernice za buduće postupke pri organizaciji prijevoza drva. Pri tome su najčešće iskazivani organizacijski parametri udio vožnje natovarenoga vozila u ukupnoj prijeđenoj udaljenosti tijekom određenoga razdoblja, tehnička ispravnost vozila i stupanj iskorištenosti vozila tijekom određenoga vremena (Rajsman 1990). Stupanj iskorištenosti vozila odražava prosječno stanje opće zaposlenosti, odnosno stupanj prisutnosti određene skupine vozila na radu tijekom promatranoga razdoblja (Arnold 2007).

Cilj je ovoga rada napraviti analizu podataka o ukupnim prevezenim količinama drva i potrošnji goriva po jedinici prevezenoga tereta, koja je najbolji pokazatelj energetske učinkovitosti prijevoza, te, nadalje, razmotriti podatke o stupnju iskorištenosti, tehničke ispravnosti te odnosa opterećene i neopterećene vožnje šumskih kamionskih skupova na primjeru prijevoznih sredstva u vlasništvu tvrtke Hrvatske šume d.o.o. Zagreb, Uprave šuma podružnica Bjelovar.

\section{Materijal i metode Material and methods}

Istraživanje je provedeno na osnovi prikupljenih podataka o radu 15 šumskih kamionskih skupova u vlasništvu Hrvatskih šuma d.o.o., Uprave šuma podružnice Bjelovar tijekom 2017. godine. Šumski su kamionski skupovi podijeljeni po tipovima s obzirom na proizvođača kamiona.

Za analizu su kamionskih skupova za prijevoz drva uzeti ovi osnovni podaci:

$\Rightarrow$ tip vozila

$\Rightarrow$ starost vozila

$\Rightarrow$ prijeđeni kilometri (pun, prazan)

$\Rightarrow$ broj turnusa

$\Rightarrow$ prevezeno oblovine $\left(\mathrm{m}^{3}\right)$

$\Rightarrow$ potrošnja goriva (L)

$\Rightarrow$ godišnji dani rada (u radu, tehnički ispravan izvan rada, u kvaru).

Svi su podaci razvrstani po tablicama i obrađeni u računalom programu Microsoft Excel.

$\mathrm{Na}$ temelju ukupne potrošnje goriva, ukupno prevezenoga drva i ukupno ostvarenih kilometara izračunata je jedinična potrošnja goriva izražena 
u L/100 km i L/m³. Prema prikupljenim podacima nije bilo moguće utvrditi prevezenu količinu drvnih sortimenata po vrstama drva na osnovi kojih se pretvara obujam tovara u masu tovara. Stoga nije prikazana, u šumarskoj praksi često korištena, potrošnja goriva po tona kilometru (L/tkm).

Također su izračunate vrijednosti udjela vožnje punih (natovarenih) šumskih kamionskih skupova u ukupno prijeđenoj udaljenosti te stupanj iskorištenosti i tehničke ispravnosti ispitivanih šumskih kamionskih skupova.

\section{Rezultati istraživanja s raspravom Research results and discussion}

U tablici 1 prikazani su prikupljeni podaci o tipovima šumskih kamionskih skupova, starosti svakoga pojedinoga vozila, godišnjoj prijeđenoj udaljenosti i broju ostvarenih radnih turnusa, ukupnoj godišnjoj količini prevezenoga drva te ukupnoj godišnjoj potrošnji goriva. Iz tih je podataka izračunata prosječna veličina tovara te jedinična potrošnja goriva $\left(\mathrm{L} / 100 \mathrm{~km}, \mathrm{~L} / \mathrm{m}^{3} \mathrm{i} \mathrm{L} / \mathrm{m}^{3} \mathrm{~km}\right)$.

Istraživani šumski kamionski skupovi prosječno su u uporabi 12,3 godina. Najstariji je šumski kamionski skup 24 godine u uporabi, dok su dva nabavljena sredinom 2017. godine $\mathrm{u}$ kojoj je provedena analiza podataka. Iz podataka su uočljiva neravnomjerna razdoblja nabave novih šumskih kamion- skih skupova u Upravi šuma podružnica Bjelovar. Tijekom 24 godine čak je sedam godina prošlo bez nabave novoga šumskoga kamionskoga skupa.

Posljednja dva nova šumska kamionska skupa ističu se manjim vrijednostima ukupno prijeđenih udaljenosti i prevezenoga drva zbog njihova korištenja tijekom polugodišnjega razdoblja.

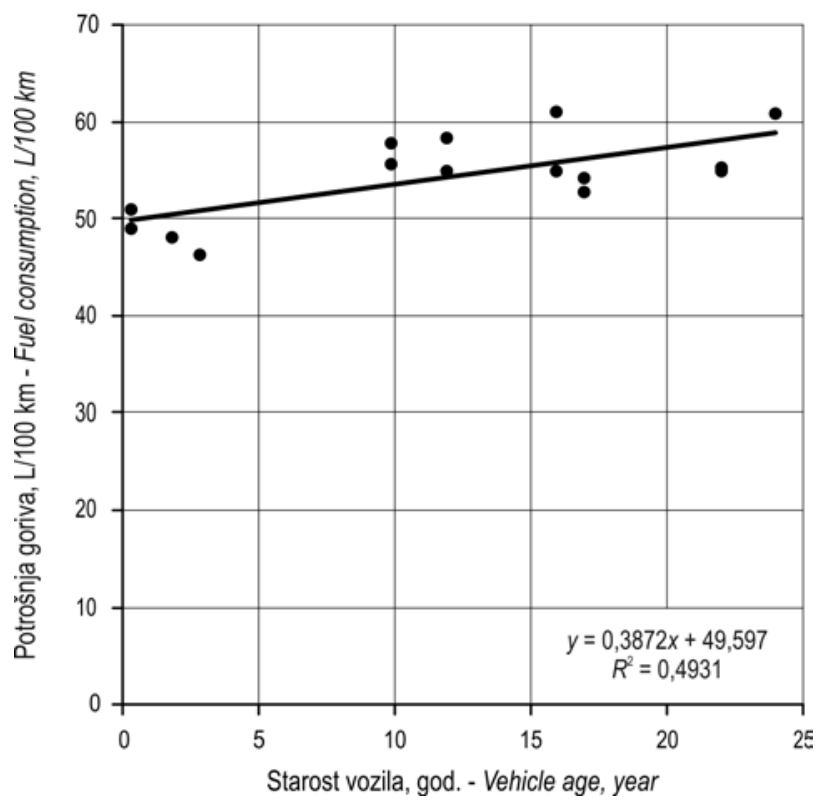

Slika 1. Potrošnja goriva šumskih kamionskih skupova (L/100 km) Fig. 1 Fuel consumption of forest trucks with trailers $(\mathrm{L} / 100 \mathrm{~km})$

Tablica 1. Godišnji pokazatelji rada šumskih kamionskih skupova Table 1 Annual work inidicators of forest trucks with trailers

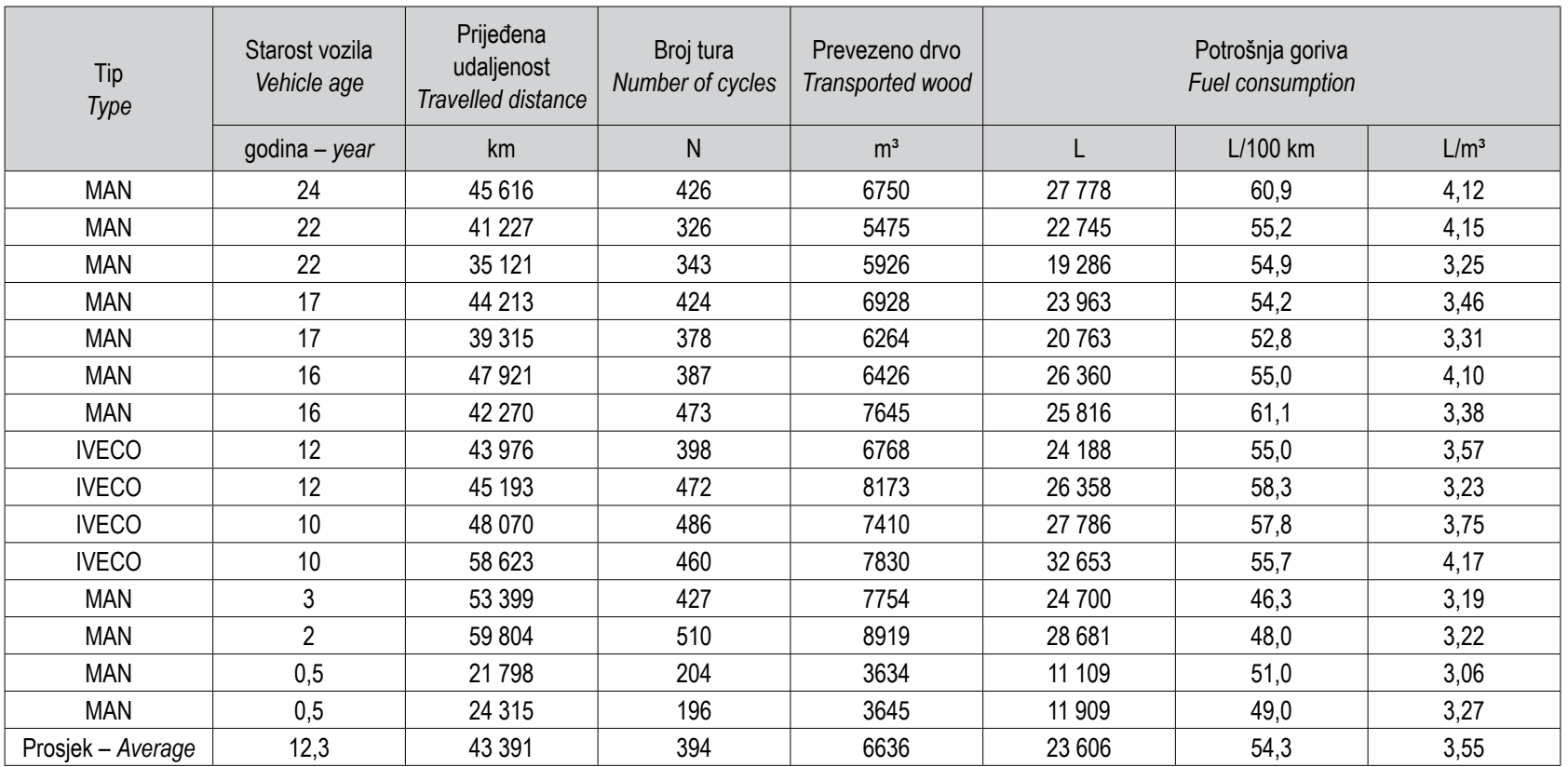


Iz slike 1 može se vidjeti kako potrošnja goriva raste s obzirom na godine uporabe šumskih kamionskih skupova. Tako je najstariji šumski kamionski skup ostvario prosječnu potrošnju goriva od 60,9 L/100 km. Neznatno veću potrošnju goriva imao je šumski kamionski skup od 16 godina starosti - 61,1 $\mathrm{L} / 100 \mathrm{~km}$, ali je ujedno prevezao i 47 tura više od najstarijega šumskoga kamionskoga skupa. Najmanji su potrošači goriva najnoviji šumski kamionski skupovi do tri godine starosti, kod kojih je zabilježena potrošnja između 46,3 i $51 \mathrm{~L} / 100 \mathrm{~km}$, što je manje za čak 10 litara od najstarijih kamionskih skupova.

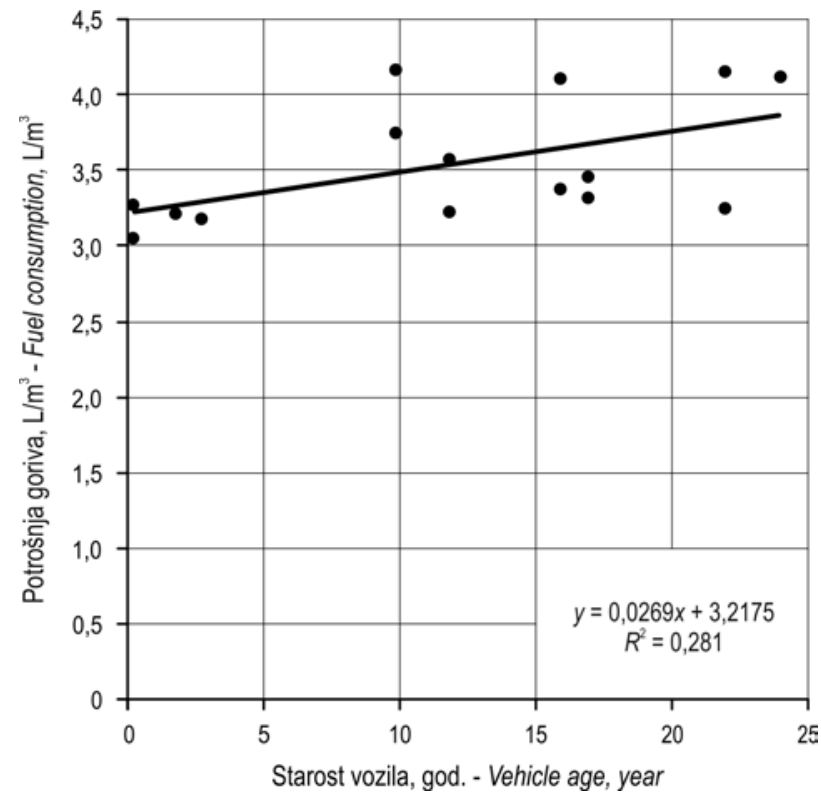

Slika 2. Jedinična potrošnja goriva šumskih kamionskih skupova $\left(\mathrm{L} / \mathrm{m}^{3}\right)$

Fig. 2 Unit fuel consumption of forest trucks with trailers $\left(\mathrm{L} / \mathrm{m}^{3}\right)$

Jedinična potrošnja goriva $\left(\mathrm{L} / \mathrm{m}^{3}\right)$ također se povećava sa starošću šumskih kamionskih skupova (slika 2). Najmanju potrošnju goriva s obzirom na prevezene količine drva imaju šumski kamionski skupovi do tri godine starosti $\left(3,06 \mathrm{~L} / \mathrm{m}^{3}\right.$ do $\left.3,27 \mathrm{~L} / \mathrm{m}^{3}\right)$. Prema prikazanim rezultatima vidljive su razlike između jedinične potrošnje goriva najstarijih šumskih kamionskih skupova. Sumski kamionski skup starosti 22 godine, s potrošnjom od $3,25 \mathrm{~L} / \mathrm{m}^{3}$, usporediv je $\mathrm{s}$ najnovijim šumskim kamionskim skupovima. Drugi šumski kamionski skup iste starosti ostvario je jediničnu potrošnju goriva od $4,12 \mathrm{~L} / \mathrm{m}^{3}$, pri čemu je prevezao $451 \mathrm{~m}^{3}$ drvnih sortimenata manje. Razlozi tomu mogu upućivati na različit obujam tovara zbog prijevoza različitih drvnih sortimenata (tehničkoga obloga drva i višemetarskoga prostornoga drva) ili na različite načine vožnje uz pretpostavku rada u sličnim uvjetima (stanje šumskih cesta, udaljenost vožnje) na istraživanom području.

Ostvarena potrošnja goriva istraživanih šumskih kamionskih skupova različite starosti uspoređena je $\mathrm{s}$ rezultatima prijašnjih sličnih istraživanja.

Karjalainen i Asikainen (1996) navode kako potrošnja goriva $u$ kamionskom prijevozu u Finskoj iznosi $56 \mathrm{~L} / 100 \mathrm{~km}$. Iste iznose potrošnje goriva utvrđuje Lindholm (2006) u švedskom šumarskom sektoru. No, prema Svensonu (2011) potrošnju goriva pri kamionskom prijevozu drva u Śvedskoj iznosi $28 \mathrm{~L} / 100 \mathrm{~km}$, ali pri većim udaljenostima prijevoza na ravnim terenima. U istraživanjima kamionskoga prijevoza drva Holzleitner i dr. (2011) utvrđuju prosječni utrošak goriva od $77 \mathrm{~L} / 100 \mathrm{~km}$ te 2,09 L/ $\mathrm{m}^{3}$ drva. Prema Klvaču (2013) potrošnja goriva šumskih kamionskih skupova iznosi 2,19 L/ $\mathrm{m}^{3}$, odnosno $67,4 \mathrm{~L} / 100 \mathrm{~km}$. Zorić i dr. (2014) utvrđuju prosječnu potrošnju goriva šumskih kamionskih skupova od $2,73 \mathrm{~L} / \mathrm{m}^{3}$, odnosno $66 \mathrm{~L} / 100 \mathrm{~km}$. Istraživanje potrošnje goriva za prijevoz drva u Australiji pokazalo je rezultat od $67 \mathrm{~L} / 100 \mathrm{~km}$ za šumske kamionske skupove, odnosno $62 \mathrm{~L} / 100 \mathrm{~km}$ za kamion bez prikolice (Ghaffariyan i dr. 2015).

Prosječna vrijednost potrošnje goriva od 54,3 $\mathrm{L} / 100 \mathrm{~km}$ svih istraživanih šumskih kamionskih skupova manja je od prijašnjih rezultata istraživanja, a posebno se nižom potrošnjom ističu najnoviji šumski kamionski skupovi. No, jedinična potrošnja po obujmu prevezenoga drva veća je od rezultata prijašnjih istraživanja, čak i kod najnovijih šumskih kamionskih skupova.

U tablici 2 prikazani su podaci o tipovima šumskih kamionskih skupova, starosti svakoga pojedinoga vozila, prijeđenoj godišnjoj udaljenosti natovarenih i praznih šumskih kamionskih skupova te udjeli vožnje s tovarom.

Gotovo svaki šumski kamionski skup imao je više prijeđenih kilometara $s$ punim tovarom nego praznim. Izuzetak je samo jedan šumski kamionski skup koji je s punim tovarom prošao 23529 kilometara, a s praznim 24392 kilometra te je ostvario 49 $\%$ pune vožnje u ukupnom prijeđenom putu. Najviše kilometara s punim tovarom prošao je šumski kamionski skup MAN koji je imao dvije godine - 30972 kilometra, dok je prazan bio u vožnji 28832 kilometra, što iznosi $52 \%$ pune vožnje u ukupnom prijeđenom putu. Najveći udio pune vožnje od $55 \%$ ostvario je najnoviji šumski kamionski skup MAN iz 2017. godine, gdje je pun tovar bio na relaciji 11953 kilometra, a prazan 9845 kilometara. Pri tome je potrebno napomenuti da su dva najnovija šumska kamionska skupa bila u radnom procesu samo pola godine. 
Tablica 2. Udio pune vožnje Table 2 Proportion of loaded travel

\begin{tabular}{|c|c|c|c|c|c|}
\hline \multirow{2}{*}{$\begin{array}{c}\text { Tip } \\
\text { Type }\end{array}$} & \multirow{2}{*}{$\begin{array}{c}\text { Starost vozila, god. } \\
\text { Vehicle age, year }\end{array}$} & \multicolumn{3}{|c|}{$\begin{array}{c}\text { Prijeđena udaljenost, } \mathrm{km} \\
\text { Travelled distance, } \mathrm{km}\end{array}$} \\
\cline { 3 - 6 } & & $\begin{array}{c}\text { Natovaren } \\
\text { Loaded }\end{array}$ & $\begin{array}{c}\text { Prazan } \\
\text { Empty }\end{array}$ & $\begin{array}{c}\text { Ukupno } \\
\text { Total }\end{array}$ & Udio pune vožnje, \% \\
Proportion of loaded travel, \% \\
\hline MAN & 24 & 23262 & 22354 & 45616 & 0,51 \\
\hline MAN & 22 & 21813 & 19414 & 41227 & 0,53 \\
\hline MAN & 22 & 17897 & 17224 & 35121 & 0,51 \\
\hline MAN & 17 & 22875 & 21338 & 44213 & 0,52 \\
\hline MAN & 17 & 19506 & 19809 & 39315 & 0,50 \\
\hline MAN & 16 & 23529 & 24392 & 47921 & 0,49 \\
\hline MAN & 16 & 20961 & 21309 & 42270 & 0,50 \\
\hline IVECO & 12 & 22460 & 21516 & 43976 & 0,51 \\
\hline IVECO & 12 & 23262 & 21931 & 45193 & 0,51 \\
\hline IVECO & 10 & 23845 & 24225 & 48070 & 0,50 \\
\hline IVECO & 10 & 29073 & 29550 & 58623 & 0,50 \\
\hline MAN & 3 & 28878 & 24521 & 53399 & 0,54 \\
\hline MAN & 2 & 30972 & 28832 & 59804 & 0,52 \\
\hline MAN & 0,5 & 11953 & 9845 & 21798 & 0,55 \\
\hline MAN & 0,5 & 13093 & 11222 & 24315 & 0,54 \\
\hline
\end{tabular}

Ukupni se godišnji radni dani sastoje od dana u radu šumskih kamionskih skupova, dana u kvaru te dana kada tehnički ispravna vozila nisu u radnom procesu zbog organizacijskoga nedostatka radova, obavljanja redovitoga održavanja i tehničkoga pregleda vozila te zbog nedostatka vozača. Istraživanim šumskim kamionskim skupovima za koje su prikupljeni cjelogodišnji podaci prosječno se vodila evidencija za oko 260 radnih dana godišnje (od 259 do 265 dana godišnje).
Stupanj iskorištenosti izračunat je kao odnos dana u radu šumskoga kamionskoga skupa prema ukupno evidentiranim godišnjim radnim danima. Tehnička je ispravnost odnos zbroja dana u radu i dana izvan radnoga procesa tehnički ispravnoga šumskoga kamionskoga skupa prema ukupno evidentiranim godišnjim radnim danima. (Tablica 3).

Tablica 3. Stupanj iskorištenosti i tehnička ispravnost šumskih kamionskih skupova

Table 3 Utilization rate and tehnical validity of forest trucks with trailers

\begin{tabular}{|c|c|c|c|c|c|c|c|}
\hline \multirow{2}{*}{$\begin{array}{l}\text { Tip } \\
\text { Type }\end{array}$} & \multirow{2}{*}{$\begin{array}{l}\text { Starost vozila, god. } \\
\text { Vehicle age, year }\end{array}$} & \multicolumn{4}{|c|}{ Dani-Days } & \multirow{2}{*}{$\begin{array}{c}\text { Stupanj } \\
\text { iskorištenosti } \\
\text { Utilization rate }\end{array}$} & \multirow{2}{*}{$\begin{array}{c}\text { Tehnička } \\
\text { ispravnost } \\
\text { Tehnical validity }\end{array}$} \\
\hline & & $\begin{array}{c}\text { U radu } \\
\text { In operation }\end{array}$ & $\begin{array}{c}\text { Izvan rada } \\
\text { Out of operation }\end{array}$ & $\begin{array}{l}\text { U kvaru } \\
\text { Out of order }\end{array}$ & $\begin{array}{c}\text { Ukupno } \\
\text { Total }\end{array}$ & & \\
\hline MAN & 24 & 202 & 10 & 49 & 261 & 0,77 & 0,81 \\
\hline MAN & 22 & 183 & 14 & 63 & 260 & 0,70 & 0,76 \\
\hline MAN & 22 & 167 & 19 & 75 & 261 & 0,64 & 0,71 \\
\hline MAN & 17 & 192 & 18 & 51 & 261 & 0,74 & 0,80 \\
\hline MAN & 17 & 184 & 15 & 63 & 262 & 0,70 & 0,76 \\
\hline MAN & 16 & 204 & 19 & 38 & 261 & 0,78 & 0,85 \\
\hline MAN & 16 & 207 & 22 & 33 & 262 & 0,79 & 0,87 \\
\hline IVECO & 12 & 190 & 11 & 58 & 259 & 0,73 & 0,78 \\
\hline IVECO & 12 & 202 & 28 & 30 & 260 & 0,78 & 0,88 \\
\hline IVECO & 10 & 206 & 31 & 24 & 261 & 0,79 & 0,91 \\
\hline IVECO & 10 & 228 & 26 & 11 & 265 & 0,86 & 0,96 \\
\hline MAN & 3 & 212 & 34 & 14 & 260 & 0,82 & 0,95 \\
\hline MAN & 2 & 236 & 17 & 8 & 261 & 0,90 & 0,97 \\
\hline MAN & 0,5 & 87 & 17 & 1 & 105 & 0,83 & 0,99 \\
\hline MAN & 0,5 & 90 & 9 & 6 & 105 & 0,86 & 0,94 \\
\hline
\end{tabular}




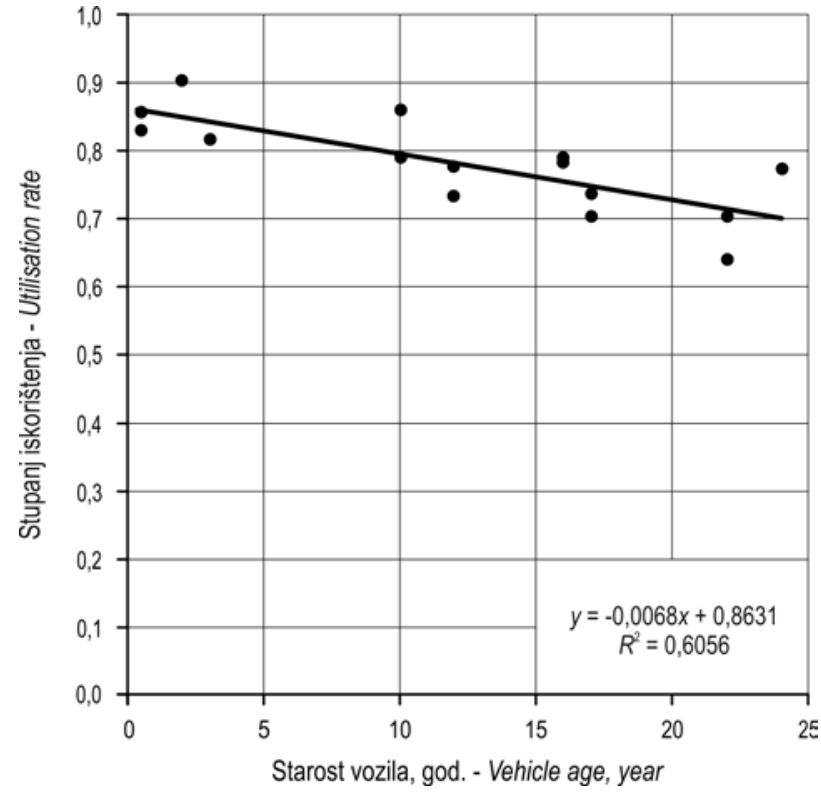

Slika 3. Stupanj iskorištenosti šumskih kamionskih skupova Fig. 3 Utilization rate of forest trucks with trailers

Stupanj se iskorištenosti kreće od 0,64 do 0,90 i vidljivo je kako on pada sa starošću, tj. godinama uporabe šumskih kamionskih skupova (slika 3.). Najveći stupanj iskorištenosti zabilježen je kod novijega dvogodišnjega šumskoga kamionskoga skupa s rezultatom 0,90 . Najmanji je stupanj iskorištenosti kod 22 godine staroga šumskoga kamionskoga skupa $(0,64)$, koji je ujedno imao najmanje dana u radu (167 dana) i najviše dana u kvaru (75 dana) od svih istraživanih vozila.

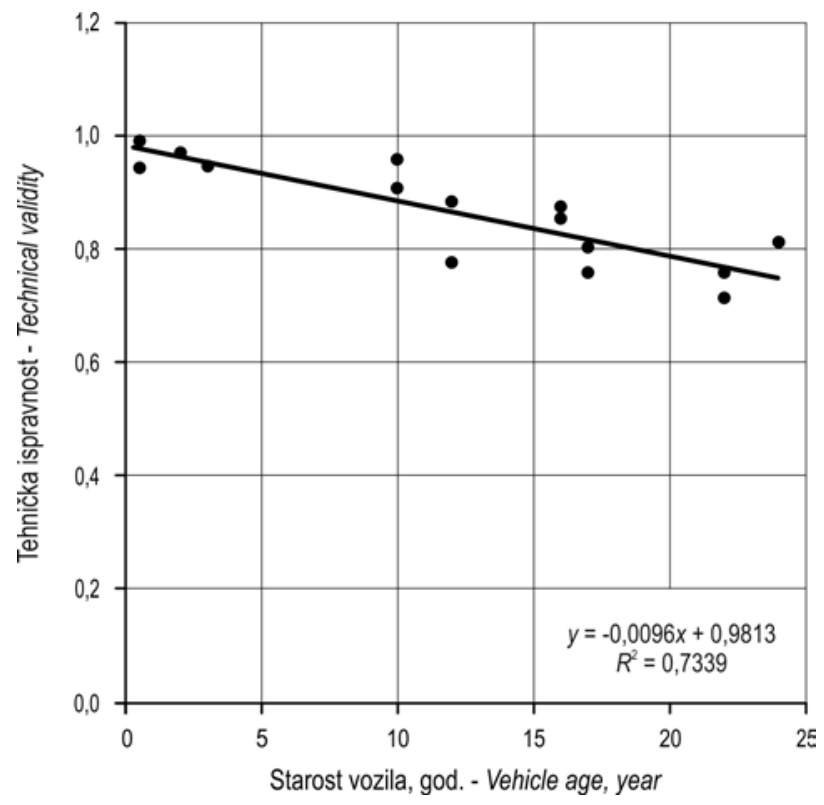

Slika 4. Tehnička ispravnost šumskih kamionskih skupova Fig. 4 Tehnical validity of forest trucks with trailers
Također, tehnička ispravnost šumskih kamionskih skupova pada sa starošću, tj. godinama uporabe (slika 4). Najveća tehnička ispravnost zabilježena je kod šumskih kamionskih skupova do 10 godina starosti, koja se kreće $\mathrm{u}$ rasponu od 0,91 do 0,99. Tehnička ispravnost od 0,99 pripada najnovijemu vozilu, koje je od 105 ukupnih dana radilo 87 dana sa 17 dana izvan radnoga procesa i samo jedan dan popravka. Najmanja je tehnička ispravnosti bila kod šumskoga kamionskoga skupa starosti 22 godine koji je bio 75 dana u kvaru. Općenito, broj se dana u kvaru šumskih kamionskih skupova do 10 godina starosti kreće $\mathrm{u}$ rasponu od 1 do 24 dana. Usporedbom sa starijim šumskih kamionskim skupovima broj dana provedenih u kvaru gotovo je trostruko manji.

\section{Zaključak - Conclusion}

Provedenom analizom šumskih kamionskih skupova tijekom jedne godine može se zaključiti da tehničku ispravnost zadovoljavaju vozila do deset godina starosti. Nakon toga se značajno povećavaju dani vozila provedenih u kvaru i na popravku.

Prosječna vrijednost potrošnje goriva od 54,3 $\mathrm{L} / 100 \mathrm{~km}$ svih istraživanih šumskih kamionskih skupova manja je od prijašnjih rezultata istraživanja, a posebno se nižom potrošnjom ističu najnoviji šumski kamionski skupovi. No, jedinična potrošnja po obujmu prevezenoga drva veća je od rezultata prijašnjih istraživanja, čak i kod najnovijih šumskih kamionskih skupova. Razlozi tomu možda leže u činjenici da starija vozila nisu opremljena sustavima mjerenja osovinskoga opterećenja te se tovare s manjim drvnim obujmom kako bi se zadovoljili zakonski kriteriji pri prijevozu drva na javnim prometnicama. Također se razlike mogu očitivati kod većega udjela prijevoza višemetarskoga prostornoga drva u odnosu na prijevoz tehničkoga obloga drva. Taj podatak može upućivati na manje udjele pune vožnje.

Prosječni postotni iznos pune vožnje šumskih kamionskih skupova od $51 \%$ zadovoljava, ali potrebno je pronaći bolja organizacijska rješenja za povećanje udjela pune vožnje. Ujedno bi se time smanjila jedinična potrošnja goriva po prevezenom drvnom obujmu. Svakako je bitno napomenuti kako zbog sve veće prisutnosti privatnih autoprijevoznika na tržištu nije u potpunosti moguća maksimalna organizacija provedbe povratnih tura. Također, organizacijskim bi mjerama trebalo u što većem opsegu planirati prijevoz drva na kraćim udaljenostima.

Proizvodnja šumskih kamionskih skupova starijih generacija razlikovala se od današnje te trenutačno ne postoji mogućnost implementacije una- 
prijeđenih tehničkih značajki na većinu starijih generacija šumskih kamionskih skupova. Modernizacijom konstrukcije šumskih kamionskih skupova može se očekivati smanjenje potrošnje goriva, što je vidljivo u rezultatima istraživanja kod kamionskih skupova novijih generacija. Primjerice, Loforth i Lindholm (2005) smatraju da se potrošnja goriva može smanjiti za $5-10 \%$ poboljšanjem aerodinamičnosti kamiona. Zorić (2012) navodi primjenu novih tehničkih rješenja radi povećanja korisne nosivosti šumskih kamionskih skupova, koja mogu pridonijeti povećanju iskorištenosti i smanjenju jedinične potrošnje goriva kamionskih skupova.

Kako bi se unaprijedio daljinski prijevoz drva šumskim kamionskim skupovima te smanjila potrošnja goriva, potrebno je pomoću sustava daljinskoga praćenja vozila (FMS-a) provesti daljnju i detaljniju analizu rada. Također je potrebno ujednačiti kriterije unosa podataka o tehničkoj ispravnosti i stupnju iskorištenosti vozila, odnosno evidenciji i raspodjeli ukupno godišnjih radnih dana. S navedenim postupcima omogućilo bi se svrhovitije korištenje podataka za analizu stanja skupina vozila radi postavljanja smjernica bolje organizacije rada daljinskoga prijevoza drva šumskim kamionima.

\section{Literatura-References}

Arnold, D., H. Isermann, A. Kuhn, H. Tempelmeier, K. Furmans, 2007: Handbuch Logistik. Springer-Verlag Berlin Heidelberg, 1117 p. https://doi.org/10.1007/978-3-540-72929-7

Carrette, T., C. Ginet, 2014: Analysis of wood transport practices and infrastructures to anticipate regulatory constrains. Proceedings of $47^{\text {th }}$ International symposium FORMEC'14: Forest engineering: propelling the forest value chain, September 23-26, 2014, Gerardmer, France, 4 p.

Devlin, G., 2010: Fuel consumption of timber haulage versus general haulage. Harvesting/transportation No. 22. COFORD, 6 p.

Favreau, J., 2006: Six key elements to reduce forest transportation cost. FERIC. Available on http://www.forac.ulaval.ca/fileadmin/docs/EcoleEte/2006/Favreau.pdf

Ghaffariyan, M. R., C. Barrier, M. Brown, M. Kuehmaier, M. Acuna, 2018: A short review of timber truck fuel consumption studies. Industry Bulletin 21, Technical report, 1-6.

Ghaffariyan, M. R., R. Spinelli, N. Magagnotti, M. Brown, 2015: Integrated harvesting for conventional log and energy wood assortments: a case study in a pine plantation in Western Australia. Southern Forests: a Journal of Forest Science, 77(4): 249-254. https://doi.org/10.2989/20702620.2015.1052946

Greulich, F., 2002: Transportation networks in forest harvesting: Early development of the theory. Proceedings of the International Seminar on New Roles of Plantation Forestry Requiring Appropriate Tending and Harvesting Opreations,
September 29-October 5, 2002, Tokyo, Japan, 1-9.

Griffin, R., M. Brown, 2010: Forest truck fuel consumption survey. CRC for Forestry Bulletin. Harvesting and Operations Bulletin, 8: 1-3.

Guimaraes, P. P., J. E. Arce, E. da Silva Lopes, A. L. Pelissari, G. Salami, V. G. de Castro, 2016: Modeling of fuel consumption for forest transportation. Rev. Caatinga, 29(2): 496-506. https://doi.org/10.1007/s10342-010-0431-y

Karjalainen, T., A. Asikainen, 1996: Greenhouse gas emissions from the use of primari energy in forest operations and longdistance transportation of timber in Finland. Forestry, 69(3): 215-228. https://doi.org/10.1093/forestry/69.3.215

Klvač, R., J. Kolarik, M. Volona, K. Drapela, 2013: Fuel consumption in timber haulage. Croatian Journal of Forest Engineering, 34(2): 229-240.

Krpan, A. P. B., D. Horvat, T. Poršinsky, M. Šušnjar, 2002: Tehničke i tehnološke značajke kamiona SCANIA P124 B 6x4 NZ 400, prikolice Narkö i dizalica Jonsered 1090. Studija, Zavod za iskorištavanje šuma, Šumarski fakultet Sveučilišta u Zagrebu.

Lindholm, E. L., 2006: Energy use in Swedish forestry and its environmental impact. Licentiate thesis 004, SLU Uppsala, 1-28.

Protega, V., 2010: Nastavni materijal za predavanje iz kolegija Osnove tehnologije prometa, nastavna cjelina Tehnologija cestovnog prometa, Fakultet prometnih znanosti, Zagreb, 1-64.

Rajsman, M., 1990: Postojeće stanje i racionalizacija cestovnog transporta PIK-a Vinkovci. Promet, 1(12): 1-28.

Sever, S., 1992: Šumarski strojevi, u: Tehnička enciklopedija. Leksikografski zavod Miroslav Krleža, Zagreb, sv. 12, 519-531.

Svenson, G., D. Fjeld, 2016. The impact of road geometry and surface roughness on fuel consumption of logging trucks. Scandinavian Journal of Forest Research, 31(5): 526-536. https://doi.org/10.1080/02827581.2015.1092574

Svenson, G., 2011: The impact of road characteristics on fuel consumption for timber trucks. In: P. Ackerman, H. Ham, E. Gleasure (eds), Proceedings of $4^{\text {th }}$ Forest Engineering Conference: Innovation in Forest Engineering - Adapting to Structural Change. Stellenbosch University, p. 172.

Šušnjar, M., D. Horvat, Z. Pandur, M. Zorić, 2011a: Određivanje osovinskih opterećenja kamionskog i šleperskog skupa za prijevoz drva. Croatian Journal of Forest Engineering, 32(1): 379-388.

Šušnjar, M., D. Horvat, M. Zorić, Z. Pandur, D. Vusić, Ž. Tomašić, 2011b: Comparison of real axle loads and wheel pressure of truck units for wood transportation with legal restrictions. Proceedings of $44^{\text {th }}$ International Symposium FORMEC'11: Pushing the boundaries with research and innovation in forest engineering, October 9-12, 2011, Graz, Austria, 1-11.

Šušnjar, M., Z. Pandur, M. Bačić, M. Zorić, 2016: Raspodjela mase tovara i osovinskoga opterećenja šumskih kamionskih skupova pri prijevozu jelova celuloznoga drva. Nova mehanizacija šumarstva, 37: 47-58. 
Tomašić, Ž., Z. Sučić, M. Slunjski, M. Polaček, 2005: Ovodobno stanje prijevoza drva kamionskim skupovima u hrvatskom šumarstvu. Nova mehanizacija šumarstva, 26(1): 65-71. Tomašić, Ž., M. Šušnjar, D. Horvat, 2012: Cooperation of Croatian forestry science and practice in development of forest engineering sector. Proceedings of $45^{\text {th }}$ International Symposium FORMEC '12, October 8-12, Dubrovnik, Croatia, 1-19.

Zorić, M., 2012: Inovacije u kamionskom prijevozu drva »One stack more«. Nova mehanizacija šumarstva, 33: 69-78.
Zorić, M., 2015: Uporaba novih mjernih sustava za određivanje energijske i tehničke pogodnosti kamionskog prijevoza drva. Doktorski rad, Šumarski fakultet Sveučilišta u Zagrebu, 1-154.

Zorić, M., M. Šušnjar, Z. Pandur, K. Mihaljević, 2014: Potrošnja goriva i emisija stakleničkih plinova pri kamionskom prijevozu drva u hrvatskom šumarstvu. Nova mehanizacija šumarstva, 35: 98-97.

\section{Abstract}

\section{Analysis of Working Features of Forest Truck Units for Timber Transport}

The study was carried out on 15 different forest trucks with trailers (forest truck units) for timber transport owned by the company »Hrvatske šume « d.o.o. Zagreb, Forestry Administration Bjelovar. The basic data used for the analysis of forest truck units are: mileage (full, empty), total fuel consumption, number of working days (in operation, out of order, technically correct but out of operation), quantity of transported timber, number of turns, age and type of vehicles. The data analysis showed the fuel consumption according to several criteria, the utilization rate and technical validity of the forest truck units and the driving relation considering the full/empty ratio. Based on the results of the research, recommendations are made on the organizational solutions of the timber truck transport and guidelines are given for the technical improvement and modernization of forest trucks and trailers.

According to the analysis of forest truck units over the one year period, vehicles up to 10 years of age meet the technical requirements. As the age of the vehicles increases, the days of malfunctioned and repaired vehicles will increase significantly.

The average fuel consumption value of $54.3 \mathrm{~L} / 100 \mathrm{~km}$ of all investigated vehicles is lower than the previous survey results, and the lower consumption of the newest forest truck units stands out. However, unit fuel consumption per volume of transported timber is higher than the results of previous research, even with the newest forest truck rallies. The reason for this may lie in the fact that older vehicles are not equipped with axle load measurement systems and are loaded with smaller timber volumes to meet legal criteria when transporting timber on public roads. Likewise, this information may indicate smaller proportions of full driving. The average percentage of full truck forest rallies of $51 \%$ is satisfactory, but better organizational solutions need to be found to increase the share of full truck rides. It would also reduce unit fuel consumption by the volume of timber transported.

Keywords: forest truck unit, fuel consumption, tehnical validity, utilization rate

Primljeno (Received): 27. 9. 2019.

Prihvaćeno (Accepted): 14. 10. 2019.

Adrese autorâ - Authors' addresses:

Prof. dr. sc. Marijan Šušnjar e-pošta: susnjar@sumfak.hr Marin Bačić, mag. ing. silv.* e-pošta: mbacic1@sumfak.hr Doc. dr. sc. Zdravko Pandur e-pošta:pandur@sumfak.hr Šumarski fakultet Sveučilišta u Zagrebu

Zavod za šumarske tehnike i tehnologije Svetošimunska 25 10000 Zagreb HRVATSKA
Tomislav Horvat, mag. ing. silv. e-pošta: tome0106990@gmail.com II. Ravnice 1A 10000 Zagreb HRVATSKA

*Glavni autor - Corresponding author 